\title{
ANALISA DAMPAK INVESTASI TEKNOLOGI INFORMASI PROYEK DATA WAREHOUSE PADA PERGURUAN TINGGI SWASTA DENGAN METODE SIMPLE ROI
}

\author{
Spits Warnars Harco Leslie Hendric \\ Fakultas Teknologi Informasi, Universitas Budi Luhur \\ Jl. Petukangan Utara, Kebayoran Lama, Jakarta Selatan 12260, Indonesia \\ E-mail: spits@bl.ac.id,www.spits.8k.com
}

\begin{abstract}
ABSTRAK: Berkurangnya jumlah mahasiswa baru untuk perguruan tinggi swasta memaksa manajemen khususnya manajemen tingkat atas untuk berpaling untuk membuat sebuah informasi yang dapat membantu dalam membantu mengambil keputusan dalam rangka berkompetisi dengan perguruan tinggi lainnya. Salah satu jalan keluarnya adalah dengan membangun dengan pendekatan teknologi informasi seperti data warehouse untuk mengelola data dan memberikan pembuatan pengambilan keputusan yang paling terbaik. Simple Return on Investment (ROI) digunakan untuk menilai kelayakan proyek. Berdasarkan nilai ROI yang berkisar 698,36\% and nilai total aliran uang kas yang mencapai Rp 8.334.901.522, dapat disimpulkan bahwa proyek pengembangan data warehouse pada perguruan tinggi swasta layak untuk diimplementasikan dengan asumsi-asumsi yang ada.
\end{abstract}

Kata kunci: investasi teknologi informasi, return on investment, data warehouse, simple ROI

\begin{abstract}
The decreasing number of new students for private high education is forced the management specially high management to look for a means to generate information that will help them in their decision making process in compete with others high education. One of the solutions is to use the Information Technology like data warehouse to maintain data and give the best decision making. Simple Return On Investment (ROI) is used to asses the project justification. Based on ROI of 698.36\% and total cash flow of $R p$ 8.334.901.522, it can be concluded that the project data warehouse on private high education is feasible to be implemented within the given assumptions in the process.
\end{abstract}

Keywords: information technology investment, return on investment, data warehouse, simple ROI

\section{PENDAHULUAN}

Analisa dampak investasi Teknologi Informasi ini digunakan untuk menilai apakah pembuatan proyek data warehouse pada perguruan tinggi ini layak untuk diimplementasikan. Nilai arus kas bersih didapatkan dengan mengurangkan jumlah manfaat bersih dengan jumlah biaya, yang pada akhirnya persentase Return On Investment (ROI) akan didapatkan dengan cara membagi dengan jumlah tahun dan dibagi lagi dengan nilai investasi proyek.

Berikut ini merupakan manfaat-manfaat laporan sebagai hasil keluaran dari sistem yang berjalan dan yang digunakan oleh manajemen perguruan tinggi yaitu:

1. Mengurangi biaya administrasi pembuatan laporan

2. Mengurangi tenaga pembuatan laporan

3. Mempercepat waktu pembuatan laporan/administrasi

4. Meningkatkan jumlah mahasiswa baru
5. Meningkatkan bantuan dana dari pihak ketiga (ADB, proyek TPSDP Bank Dunia)

6. Meningkatkan produktivitas manajemen tingkat atas

7. Meningkatkan citra perguruan tinggi

8. Meningkatkan hubungan dengan stakeholder (mahasiswa, orang tua, dunia kerja, DIKTI)

9. Meningkatkan moral karyawan

10. Meningkatkan pengetahuan manajemen

11. Meningkatkan perencanaan pengelolaan data

12. Meningkatkan fleksibilitas pemanfaatan data

13. Meningkatkan kemampuan pengambilan keputusan

Ada dua tipe manfaat teknologi informasi atau sistem informasi yang umum dipakai yaitu manfaat yang terlihat (Tangible benefit) dan manfaat yang tidak terlihat (Intangible benefit). Manfaat tersebut dapat diukur (measurable benefit) dan juga sulit diukur (immeasurable benefit). Berdasarkan kategori tersebut manfaat-manfaat di atas disarikan dalam tabel matrik manfaat berikut: 
Tabel 1. Matrik Manfaat

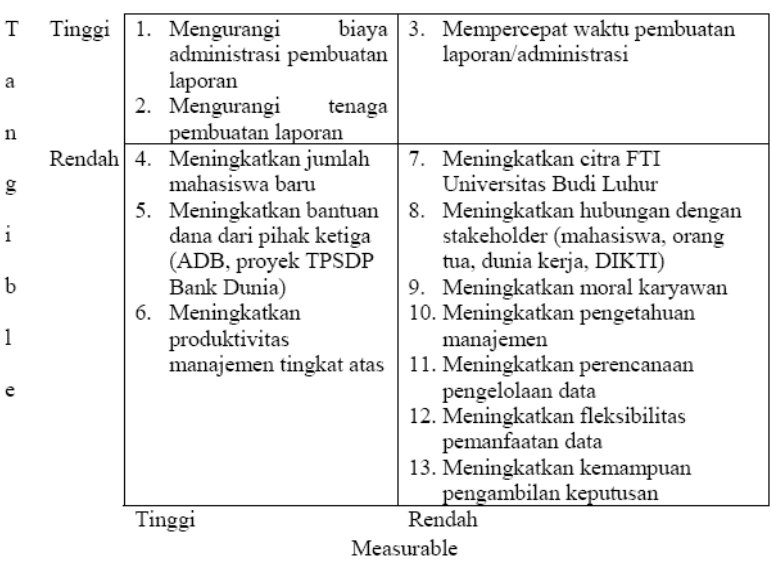

Selain itu manfaat-manfaat tersebut dipetakan menjadi Tabel 2.

\section{Tabel 2. Tabel Potensi Manfaat}

\begin{tabular}{|c|c|c|c|c|}
\hline \multirow[b]{2}{*}{ Potensi Manfaat } & \multicolumn{3}{|c|}{ Klasifikasi } & \multirow[b]{2}{*}{ Metode Pengukuran } \\
\hline & $\begin{array}{l}\text { Aspek } \\
\text { Manfaat }\end{array}$ & Domain & Value & \\
\hline $\begin{array}{l}\text { 1. Mengurangi biaya } \\
\text { administrasi pembuatan } \\
\text { laporan }\end{array}$ & $\begin{array}{l}\text { Tangible } \\
\text { Measurable }\end{array}$ & Teknologi & Finansial & $\begin{array}{l}\text { Analisa } \\
\text { manfaatbiaya } \\
\text { (simple ROI) }\end{array}$ \\
\hline $\begin{array}{l}\text { 2. Mengurangi tenaga } \\
\text { pembuatan } \\
\text { laporan/administrasi }\end{array}$ & $\begin{array}{l}\text { Tangible } \\
\text { Measurable }\end{array}$ & Teknologi & Finansial & $\begin{array}{l}\text { Analisa } \\
\text { manfaatbiaya } \\
\text { (simple ROI) }\end{array}$ \\
\hline $\begin{array}{l}\text { 3. Mempercepat waktu } \\
\text { pembuatan } \\
\text { laporan/administrasi }\end{array}$ & $\begin{array}{l}\text { Tangible } \\
\text { Measurable }\end{array}$ & Teknologi & $\begin{array}{l}\text { Non- } \\
\text { Finansial }\end{array}$ & $\begin{array}{l}\text { Tidak dilakukan } \\
\text { pengukuran }\end{array}$ \\
\hline $\begin{array}{l}\text { 4. Meningkatkan jumlah } \\
\text { mahasiswa baru }\end{array}$ & $\begin{array}{l}\text { Intangible } \\
\text { Measurable }\end{array}$ & Bisnis & Finansial & $\begin{array}{l}\text { Analisa } \\
\text { manfaatbiaya } \\
\text { (simple ROI) }\end{array}$ \\
\hline $\begin{array}{l}\text { 5. Meningkatkan bantuan } \\
\text { dana dari pihak ketiga } \\
\text { (ADB, proyek TPSDP, } \\
\text { Bank Dunia) }\end{array}$ & $\begin{array}{l}\text { Intangible } \\
\text { Measurable }\end{array}$ & Bisnis & Finansial & $\begin{array}{l}\text { Analisa } \\
\text { manfaatbiaya } \\
\text { (simple ROI) }\end{array}$ \\
\hline $\begin{array}{l}\text { 6. Meningkatkan } \\
\text { produktifitas manajemen } \\
\text { tingkat atas }\end{array}$ & $\begin{array}{l}\text { Intangible } \\
\text { Measurable }\end{array}$ & Bisnis & Finansial & $\begin{array}{l}\text { Analisa } \\
\text { manfaatbiaya } \\
\text { (simple ROI) }\end{array}$ \\
\hline $\begin{array}{l}\text { 7. Meningkatkan citra FTI } \\
\text { Universitas Budi Luhur }\end{array}$ & $\begin{array}{l}\text { Intangible } \\
\text { Measurable }\end{array}$ & Bisnis & $\begin{array}{l}\text { Non- } \\
\text { Finansial }\end{array}$ & $\begin{array}{l}\text { Tidak dilakukan } \\
\text { pengukuran }\end{array}$ \\
\hline $\begin{array}{l}\text { 8. Meningkatkan hubungan } \\
\text { dengan stakeholder } \\
\text { (mahasiswa, orangtua, } \\
\text { dunia kerja, DIKTI) }\end{array}$ & $\begin{array}{l}\text { Intangible } \\
\text { Measurable }\end{array}$ & Bisnis & $\begin{array}{l}\text { Non- } \\
\text { Finansial }\end{array}$ & $\begin{array}{l}\text { Tidak dilakukan } \\
\text { pengukuran }\end{array}$ \\
\hline $\begin{array}{l}\text { 9. Meningkatkan moral } \\
\text { karyawan }\end{array}$ & $\begin{array}{l}\text { Intangible } \\
\text { Measurable }\end{array}$ & Bisnis & $\begin{array}{l}\text { Non- } \\
\text { Finansial }\end{array}$ & $\begin{array}{l}\text { Tidak dilakukan } \\
\text { pengukuran }\end{array}$ \\
\hline $\begin{array}{l}\text { 10. Meningkatkan } \\
\text { pengetahuan manajemen }\end{array}$ & $\begin{array}{l}\text { Intangible } \\
\text { nMeasurable }\end{array}$ & Teknologi & $\begin{array}{l}\text { Non- } \\
\text { Finansial }\end{array}$ & $\begin{array}{l}\text { Tidak dilakukan } \\
\text { pengukuran }\end{array}$ \\
\hline $\begin{array}{l}\text { 11. Meningkatkan } \\
\text { perencanaan pengelolaar } \\
\text { data }\end{array}$ & $\begin{array}{c}\text { Intangible } \\
\text { nMeasurable }\end{array}$ & Teknologi & $\begin{array}{l}\text { Non- } \\
\text { Finansial }\end{array}$ & $\begin{array}{l}\text { Tidak dilakukan } \\
\text { pengukuran }\end{array}$ \\
\hline $\begin{array}{l}\text { 12. Meningkatkan } \\
\text { fleksibilitas pemanfaatan } \\
\text { data }\end{array}$ & $\begin{array}{l}\text { Intangible } \\
\text { Measurable }\end{array}$ & Teknologi & $\begin{array}{l}\text { Non- } \\
\text { Finansial }\end{array}$ & $\begin{array}{l}\text { Tidak dilakukan } \\
\text { pengukuran }\end{array}$ \\
\hline $\begin{array}{l}\text { 13. Meningkatkan } \\
\text { kemampuan } \\
\text { pengambilan keputusan }\end{array}$ & $\begin{array}{l}\text { Intangible } \\
\text { Measurable }\end{array}$ & Teknologi & $\begin{array}{l}\text { Non- } \\
\text { Finansial }\end{array}$ & $\begin{array}{l}\text { Tidak dilakukan } \\
\text { pengukuran }\end{array}$ \\
\hline
\end{tabular}

Terlihat dari Tabel 2, hanya manfaat yang dapat diukur (measurable) yang dapat diukur dengan metode analisa manfaat/biaya (simple ROI). Baik manfaat yang dapat diukur (measurable) yang terlihat (tangible benefit) dan yang tidak terlihat (Intangible benefit). Sedangkan untuk manfaat yang tidak dapat diukur (immeasurable) baik yang terlihat (tangible benefit) dan yang tidak terlihat (intangible benefit) tidak dilakukan pengukuran pada proyek pembuatan data warehouse pada perguruan tinggi ini. Khusus untuk manfaat meningkatkan bantuan dana dari pihak ketiga tidak dilakukan pengukuran yang dikarenakan adanya kesulitan untuk mengukur manfaat yang akan diuraikan, dan masih adanya kurangnya ketegasan manfaat ini dimana manfaat bantuan dana pihak ketiga ini bisa juga didapatkan tanpa membangun proyek pembuatan data warehouse ini.

Seluruh perhitungan proyek ini mengasumsikan batasan waktu sampai 5 tahun, yang didasarkan bahwa implementasi sebuah proyek sistem informasi akan dapat bertahan dan dirancang untuk kebutuhan 5 tahun kedepan sesuai dengan keinginan manajemen tingkat atas, sehingga ada kemungkinan 5 tahun ke depan manajemen tingkat atas dapat menilai kelayakan sebuah aplikasi sistem informasi apakah perlu dikembangkan atau diubah sama sekali.

\section{PROPOSAL PROYEK DATA WAREHOUSE}

Untuk melihat sejauh mana besarnya proyek pengembangan data warehouse ini maka di bawah ini akan diuraikan berapa personal yang terlibat dalam proyek ini, lama dan uraian kegiatan pengerjaan proyek serta biaya yang dibutuhkan untuk mengembangkan proyek ini.

\section{Waktu Pengerjaan Proyek}

Waktu pengerjaan proyek ini memakan waktu selama 1 tahun dan dengan menggunakan Tabel 3 yang merupakan gantt chart pengerjaan proyek yang akan diperlihatkan rincian proses kegiatan pengembangan proyek sebagai berikut:

\section{Tabel 3. Gantt Chart pengerjaan proyek.}

\begin{tabular}{|c|c|c|c|c|c|c|c|c|}
\hline \multirow{2}{*}{ Proses kegiatan } & \multicolumn{8}{|c|}{ Bulan } \\
\hline & \begin{tabular}{l|l|l|}
1 & 2 & 3 \\
\end{tabular} & \begin{tabular}{l|l}
4 & 5 \\
\end{tabular} & & 7 & 8 & 10 & 11 & 12 \\
\hline \multicolumn{9}{|l|}{$\begin{array}{l}\text { Analisa Laporan-laporan atau } \\
\text { informasi yang dibutuhkan }\end{array}$} \\
\hline \multicolumn{9}{|l|}{$\begin{array}{l}\text { Analisa model data logika basis } \\
\text { data sistem OLTP }\end{array}$} \\
\hline \multicolumn{9}{|l|}{ Desain Hypercubes } \\
\hline \multicolumn{9}{|l|}{$\begin{array}{l}\text { Desain model data logika Data } \\
\text { Warehouse }\end{array}$} \\
\hline \multicolumn{9}{|l|}{ Seminar awal } \\
\hline \multicolumn{9}{|l|}{$\begin{array}{l}\text { Desain struktur data fisik Data } \\
\text { Warehouse }\end{array}$} \\
\hline \multicolumn{9}{|l|}{$\begin{array}{l}\text { Desain Aplikasi ETL Data } \\
\text { Warehouse }\end{array}$} \\
\hline \multicolumn{9}{|l|}{$\begin{array}{l}\text { Desain Aplikasi OLAP Data } \\
\text { Warehouse }\end{array}$} \\
\hline Seminar akhir & & & & & & & & \\
\hline
\end{tabular}

\section{Staf Proyek yang Terlibat}

Adapun proyek pengembangan data warehouse ini akan melibatkan 6 orang staf proyek dengan rincian sebagai berikut: 
a. 1 orang kepala proyek

b. 2 orang data warehouse administrator

c. 2 orang programer

d. 1 orang administrasi

Staf proyek akan mempunyai hari kerja ditentukan mulai hari Senin sampai Jumat terhitung selama 1 tahun yaitu 260 hari kerja sesuai dengan lama proyek ini, dan setiap harinya membutuhkan waktu kerja 7 jam per hari. Dengan demikian jumlah keseluruhan jam kerja yang dibutuhkan untuk setiap orang staf pada proyek ini dalam satu tahun adalah: 7 jam/hari * 260 hari kerja = 1820 jam.

\section{Biaya Pengembangan Proyek}

Proyek pengembangan data warehouse ini membutuhkan biaya yang terdiri dari upah staf proyek, pengadaan perangkat lunak, pengadaan perangkat keras, jaringan dan biaya pendukung lainnya.

a. Upah staf proyek

Upah staf proyek dibayar per jam sesuai dengan upah per jam masing-masing staf yang dapat dilihat pada Tabel 4.

Tabel 4. upah staf proyek.

\begin{tabular}{lrrr}
\hline \multicolumn{1}{c}{ Staf } & Upah/jam & $\begin{array}{c}\text { Upah/jam * } \\
\mathbf{1 8 2 0} \text { jam }\end{array}$ & Total Bayar \\
\hline Kepala Proyek (1) & 20.000 & 36.400 .000 & 36.400 .000 \\
Data warehouse & 15.000 & 27.300 .000 & 54.600 .000 \\
administrator (2) & & & \\
Programer (2) & 10.00 & 18.200 .000 & 36.400 .000 \\
Administrasi (1) & 5.000 & 9.100 .000 & 9.100 .000 \\
\hline Total keseluruhan upah & & & 136.500 .000 \\
\hline
\end{tabular}

b. Biaya pengadaan perangkat lunak

i. Pembuatan aplikasi

Aplikasi dibuat dengan menggunakan bahasa pemrograman Java dimana bahasa pemrograman Java ini merupakan bahasa pemrograman open source, sehingga biaya untuk pengadaan bahasa pemrograman ini tidak diperlukan.

ii. Basis data

Basis data dibuat dengan menggunakan basis data Oracle, dimana saat ini perguruan tinggi diasumsikan telah beralih ke basis data Oracle $10 \mathrm{~g}$ sehingga tidak diperlukan biaya pengadaan basis data.

c. Biaya pengadaan perangkat keras

i. 1 buah server HP Proliant ML110G2-063 Intel Pentium 4 processor 540(3.2 GHz, FSB DD, cache $1 \mathrm{MB}$ ) Memory 512MB DDR400 ECC, Single Channel U320 SCSI, Hard drive 73 GB
SCSI U320 10K., 48x CD, 8MB VGA, GbE NIC, Tower Case
12.000 .000
ii. Stabilizer
30.000 .000
ii. UPS
40.000 .000

d. Biaya Jaringan

i. Switch 3Com 3C16470 SuperStack III Baseline 10/100 Mbps 16 port MDI/MDIX 10BASE-T/100 BASETX 2unit@ Rp 1.400.000 2.800 .000

ii. Kabel UTP Kategori 6

1.050 .000

iii. RJ-45 + connector shield

750.000

iv. Network Interface Card

1.200 .000

e. Biaya pendukung

i. Mengadakan Seminar

5.000 .000

ii. Peralatan Alat Tulis Kantor

2.000 .000

iii. Lain-lain

iv. Lampu cadangan

500.000

v. Rak Komputer Server

1.900 .000

f.. Total keseluruhan biaya

238.700.000

Total keseluruhan biaya untuk pengembangan proyek ini akan menjadi nilai investasi proyek ini sewaktu melakukan penghitungan analisa manfaat/ biaya dengan metode simple ROI.

\section{ANALISA BIAYA}

Sebelum melakukan perhitungan dengan menggunakan metode simple ROI ini perlu bagi kita untuk menganalisa biaya berjalan yang mendukung proyek ini serta biaya operasional yang selama ini dapat dihemat.

\section{Biaya Berjalan}

Tabel 5. Biaya berjalan proyek.

\begin{tabular}{|c|c|c|c|c|c|}
\hline Biaya & $\begin{array}{c}\text { Tahun } \\
\text { ke-1 }\end{array}$ & $\begin{array}{c}\text { Tahun } \\
\text { ke-2 }\end{array}$ & $\begin{array}{c}\text { Tahun } \\
\text { ke-3 }\end{array}$ & $\begin{array}{c}\text { Tahun } \\
\text { ke-4 }\end{array}$ & $\begin{array}{c}\text { Tahun } \\
\text { ke-5 }\end{array}$ \\
\hline \multicolumn{6}{|l|}{ A Pemeliharaan } \\
\hline Aplikasi & & & & & \\
\hline $\begin{array}{l}\text { 1. Penyempurnaan } \\
\text { sistem }\end{array}$ & 0 & 30.150 .000 & 27.135 .000 & 24.421 .500 & 21.979.350 \\
\hline \multicolumn{6}{|l|}{ B Pemeliharaan } \\
\hline Perangkat Keras & & & & & \\
\hline $\begin{array}{l}\text { 1. Peningkatan } \\
\text { memory server }\end{array}$ & 0 & 0 & 16.000 .000 & 14.400 .000 & 12.960 .000 \\
\hline $\begin{array}{l}\text { 2. Peningkatan } \\
\text { harddisk server }\end{array}$ & 0 & 0 & 24.000 .000 & 21.600 .000 & 19.440 .000 \\
\hline Total Biaya berjalan & 0 & 30.150 .000 & 67.135 .000 & 60.421 .500 & 54.379 .350 \\
\hline
\end{tabular}

Tabel 5 memperlihatkan biaya berjalan proyek dimana biaya ini adalah biaya yang dibutuhkan selama 5 tahun ke depan untuk mendukung kelancaran pelaksanaan proyek ini. Tahun ke-1 tidak ada sama sekali biaya dan dimulai tahun ke-2 dan 
biaya berkurang $10 \%$ pada tahun berikutnya, hal ini didasarkan pada asumsi inflasi Rupiah dan penyesuaian Upah Minimum Regional (UMR) sebesar $10 \%$ pertahun.

\section{Biaya operasional pembuatan laporan} puti:

Biaya operasional pembuatan laporan ini meli-

a. Administrasi pembuatan laporan

Biaya administrasi pembuatan laporan ini didapatkan dari bagian keuangan, dimana masing-masing biaya merupakan biaya per tahun yang harus dikeluarkan oleh bagian keuangan untuk mendukung pembuatan laporan-laporan yang dibutuhkan oleh manajemen tingkat atas perguruan tinggi.

Biaya administrasi pembuatan laporan meliputi biaya pengadaan:

\section{i. Kertas}

Dengan harga per rim sekitar Rp 30.000, didapatkan bahwa dalam 1 tahun menghabiskan sekitar 12 rim kertas. Kertas ini dipakai untuk mencetak hasil-hasil laporan dan memperbanyak hasil laporan untuk dijadikan bahan rapat.

ii. Tinta printer

Dalam 1 tahun dibutuhkan 1 toner printer Hp Q2613A untuk printer Hp Laser Jet 1300 yang berharga Rp 1.100.000.

iii. Tinta foto copy

Dalam 1 tahun dibutuhkan setengah toner mesin foto copy Canon tipe NPG-8 untuk mesin foto copy merk Canon tipe 6130. Toner mesin foto copy ini berharga 900.000.

iv. Honor panitia

Sesuai dengan data yang didapatkan dari bagian keuangan pelaksanaan pembuatan laporan untuk manajemen tingkat atas ini membutuhkan pembentukan panitia yang mana harus mengeluarkan honor untuk panitia yang mencapai 12.000 .000 per tahun.

v. Rapat

Sesuai dengan data yang didapatkan dari bagian keuangan dibutuhkan dana mencapai 35.000.000 untuk panitia dalam mengadakan rapat-rapat, yang kadangkala harus mengadakan rapat ke luar kota.

b. Tenaga pembuatan laporan

Pembuatan laporan biasanya melibatkan manajemen tingkat atas seperti Dekan, Ketua Program Studi, sekretaris program studi dan dibantu oleh beberapa staf pengolahan data seperti seorang sistem analis dan 2 orang programer. Selain itu didukung oleh 2 orang staf biasa yang bertugas membantu dalam penyiapan laporan dan memperbanyak laporan. Berikut ini adalah gaji per bulan untuk masing-masing staf selain manajemen tingkat atas yaitu:

i. Sistem analis 1 orang dengan gaji 5 juta per bulan.

ii. Programer 2 orang dengan gaji masing-masing 3 juta per bulan.

iii. Staf 2 orang dengan gaji masing-masing 2 juta per bulan.

Tabel 6 memperlihatkan berapa biaya operasional yang dibutuhkan pada sistem yang berjalan sebelum diterapkannya proyek ini dan diharapkan biaya ini dapat dikurangi. Biaya-biaya ini diasumsikan mengalami kenaikan $10 \%$ per tahunnya, hal ini didasarkan pada asumsi inflasi Rupiah dan penyesuaian UMR sebesar 10\% pertahun.

Tabel 6. Biaya operasional pembuatan laporan.

\begin{tabular}{|c|c|c|c|c|c|}
\hline Jenis Biaya & Tahun ke-1 & Tahun ke-2 & Tahun ke-3 & Tahun ke-4 & Tahun ke-5 \\
\hline \multicolumn{6}{|c|}{ Biaya Administrasi pembuatan laporan } \\
\hline Kertas & 360.000 & 396.000 & 435.600 & 479.160 & $\overline{527.076}$ \\
\hline Printer & 1.100 .000 & 1.210 .000 & 000 & 100 & 1.610 .510 \\
\hline & 450.000 & 495.000 & 1.500 & 598.950 & 658.845 \\
\hline 110 & 12.000 .000 & 13.200 .000 & 14.520 .000 & 5.972 .000 & 7.569 .200 \\
\hline Rapat & 35.000 .000 & 38.500 .000 & .000 & 000 & 51.243 .500 \\
\hline \multicolumn{6}{|c|}{ Biaya tenaga pembuatan laporan } \\
\hline Sistem analisis (1 & .000 .000 & 66.000 .000 & 72600000 & 79.860 .000 & 87.846 .000 \\
\hline Programmer (2 & 72.000 .000 & 79.200 .000 & 87.120 .000 & 95.832 .000 & 105.415 .200 \\
\hline Staf (2 orang) & 48.000 .000 & 52.800 .000 & 58.080 .000 & 63.888 .000 & 70.276 .800 \\
\hline $\begin{array}{l}\text { Total Biaya } \\
\text { Operasional }\end{array}$ & 228.910 .000 & 251.801.000 & 276.981.100 & 304.679 .210 & 335.147 .131 \\
\hline
\end{tabular}

MANFAAT PENGHEMATAN BIAYA OPERASIONAL

Penghematan biaya operasional pembuatan laporan ini meliputi:

\section{Administrasi pembuatan laporan}

a. Kertas

Dengan adanya data warehouse pencetakan laporan yang belum sempurna tidak diperlukan, manajemen dapat mengakses laporan secara langsung melalui aplikasi dan dapat menghemat $75 \%$ penggunaan kertas.

b. Tinta printer

Dengan adanya pengurangan pencetakan laporan yang belum sempurna dan dapat menghemat $75 \%$ penggunaan kertas, maka otomatis menghemat penggunaan tinta printer sampai $75 \%$.

c. Tinta foto copy

Dengan adanya pengurangan pencetakan laporan yang belum sempurna dan adanya fasilitas bagi manajemen tingkat atas untuk mengakses laporan secara langsung melalui aplikasi maka memper- 
banyak laporan yang belum sempurna untuk kepentingan rapat dapat dikurangi sampai $75 \%$.

d. Honor panitia

Dengan adanya adanya fasilitas bagi manajemen tingkat atas untuk mengakses laporan secara langsung melalui aplikasi, maka tidak diperlukan pembentukan panitia pada setiap pembuatan laporan untuk manajemen tingkat atas. Sehingga pengeluaran biaya honor panitia dapat dikurangi sampai $100 \%$.

e. Rapat

Dengan adanya adanya fasilitas bagi manajemen tingkat atas untuk mengakses laporan secara langsung melalui aplikasi dan tidak diperlukannya pembentukan panitia maka biaya rapat yang kadangkala harus mengadakan rapat ke luar kota dapat dikurangi sampai 75\%.

\section{Tenaga Pembuatan Laporan}

Dengan adanya adanya fasilitas bagi manajemen tingkat atas untuk mengakses laporan secara langsung melalui aplikasi maka ada kemungkinan bagi BSI (Biro Sistem Informasi) untuk mengurangi jumlah staff seperti:

a. Sistem analis 1 orang dengan gaji 5 juta per bulan.

b. Programer 2 orang dengan gaji masing-masing 3 juta per bulan.

c. Staf 2 orang dengan gaji masing-masing 2 juta per bulan

Tabel 7. Penghematan biaya operasional pembuatan laporan

\begin{tabular}{|c|c|c|c|c|c|}
\hline $\begin{array}{c}\text { Jenis } \\
\text { Penghematan }\end{array}$ & $\begin{array}{c}\text { Tahum } \\
\text { ke-1 }\end{array}$ & $\begin{array}{c}\text { Tahun } \\
\text { ke-2 }\end{array}$ & $\begin{array}{c}\text { Tahum } \\
\text { ke-3 }\end{array}$ & $\begin{array}{c}\text { Tahun } \\
\text { ke-4 }\end{array}$ & $\begin{array}{c}\text { Tahum } \\
\text { ke-5 }\end{array}$ \\
\hline \multicolumn{6}{|c|}{ Biaya Administrasi pembuatan laporan } \\
\hline Kertas (75\%) & 270.000 & $297 . .000$ & 326.700 & $359 . .370$ & 395.307 \\
\hline Tinta Printer (75\%) & 825.000 & 907.500 & 998.250 & 1.098 .075 & 1.207 .883 \\
\hline $\begin{array}{l}\text { Tinta Fotocopy } \\
\text { (75\%) }\end{array}$ & 337.500 & 371.250 & 408.375 & 449.213 & 494.134 \\
\hline $\begin{array}{l}\text { Honor panitia } \\
(100 \%)\end{array}$ & 12.000 .000 & 13.200 .000 & 14.520 .000 & 15.972 .000 & 17.569 .200 \\
\hline Biaya Rapat (75\%) & 26.250 .000 & 28.875 .000 & 31.762 .500 & 34.938 .750 & 38.432 .625 \\
\hline \multicolumn{6}{|c|}{ Biaya tenaga pembuatan laporan } \\
\hline $\begin{array}{l}\text { Sistem analisis (1 } \\
\text { orang) }\end{array}$ & 60.000 .000 & 66.000 .000 & 72.600 .000 & 79.860 .000 & 87.846 .000 \\
\hline $\begin{array}{l}\text { Programmer (2 } \\
\text { orang) }\end{array}$ & 72.000 .000 & 79.200 .000 & 87.120 .000 & 95.832 .000 & 105.415 .200 \\
\hline Staf(2 orang) & 48.000 .000 & 52.800 .000 & 58.080 .000 & 63.888 .000 & 70.276 .800 \\
\hline $\begin{array}{l}\text { Total } \\
\text { Penghemanatn }\end{array}$ & 219.682 .500 & 241.650 .750 & 265.815 .825 & 292.397 .408 & 321.637.148 \\
\hline
\end{tabular}

Tabel 7 memperlihatkan penghematan dari biaya operasional sesuai dengan prosentase penghematan masing-masing.

\section{MANFAAT MENINGKATKAN JUMLAH MAHASISWA BARU}

Melalui data warehouse diharapkan akan membantu perguruan tinggi untuk lebih matang lagi dalam membuat keputusan guna meningkatkan jumlah mahasiswa baru yang otomatis akan meningkatkan pendapatan. Sesuai dengan data penerimaan mahasiswa baru Tabel 8 memperlihatkan contoh jumlah penerimaan mahasiswa baru mencapai puncaknya pada tahun 1999 dengan jumlah 2390 mahasiswa baru. Penerimaan mahasiswa baru dari tahun 1999 hingga tahun 2005 mengalami penurunan antara 8\% sampai $46 \%$ dari tahun sebelumnya, walaupun pada tahun 2004 sempat mengalami kenaikan 10\% dari tahun sebelumnya.

\section{Tabel 8. Data penerimaan mahasiswa baru}

\begin{tabular}{|c|c|c|c|c|c|c|c|}
\hline \multirow{2}{*}{ Tahun } & \multicolumn{4}{|c|}{ Program Studi } & \multirow{2}{*}{ Total } & \multirow{2}{*}{ Selisih } & \multirow{2}{*}{ Selisih } \\
\hline & TI & SI & SK & AK & & & \\
\hline 1986 & 520 & 892 & 37 & 113 & 1.562 & & \\
\hline 1987 & 169 & 599 & 60 & 270 & 1.098 & -464 & $-30 \%$ \\
\hline 1988 & 156 & 389 & 86 & 260 & 891 & -207 & $-19 \%$ \\
\hline 1989 & 79 & 580 & 59 & 124 & 842 & -49 & $-5 \%$ \\
\hline 1990 & 142 & 1.072 & 51 & 126 & 1.391 & 549 & $65 \%$ \\
\hline 1991 & 202 & 1.078 & 33 & 71 & 1.384 & -7 & $-1 \%$ \\
\hline 1992 & 261 & 1.038 & 71 & 126 & 1.496 & 112 & $8 \%$ \\
\hline 1993 & 205 & 835 & 148 & 339 & 1.527 & 31 & $2 \%$ \\
\hline 1994 & 254 & 898 & 95 & 318 & 1.565 & 38 & $2 \%$ \\
\hline 1995 & 402 & 1.185 & 122 & 328 & 2.037 & 472 & $30 \%$ \\
\hline 1996 & 349 & 1.031 & 111 & 339 & 1.830 & -207 & $-10 \%$ \\
\hline 1997 & 525 & 1.205 & 93 & 304 & 2.127 & 297 & $16 \%$ \\
\hline 1998 & 501 & 1.081 & 156 & 256 & 1.994 & -133 & $-6 \%$ \\
\hline 1999 & 645 & 1.268 & 152 & 325 & 2.390 & 396 & $20 \%$ \\
\hline 2000 & 697 & 1.108 & 117 & 274 & 2.196 & -194 & $-8 \%$ \\
\hline 2001 & 673 & 861 & 46 & 197 & 1.777 & -419 & $-19 \%$ \\
\hline 2002 & 559 & 733 & 35 & 237 & 1.564 & -213 & $-12 \%$ \\
\hline 2003 & 455 & 534 & 32 & 193 & 1.214 & -350 & $-22 \%$ \\
\hline 2004 & 580 & 543 & 43 & 166 & 1.332 & 118 & $10 \%$ \\
\hline 2005 & 312 & 295 & 33 & 79 & 719 & -613 & $-46 \%$ \\
\hline Total & 7.686 & 17.255 & 1.580 & 4.445 & 30.936 & & \\
\hline
\end{tabular}

Diharapkan dengan dibuatnya data warehouse, manajemen tingkat atas dapat meningkatkan jumlah penerimaan mahasiswa baru sampai $20 \%$ per tahun. Angka 20\% ini merupakan nilai rata-rata dari tingkat kenaikan jumlah penerimaan mahasiswa baru $(65 \%+$ $8 \%+2 \%+2 \%+30 \%+16 \%+20 \%+10 \%) / 8=$ $19,125 \%$.

Berikut ini merupakan biaya yang harus dikeluarkan oleh mahasiswa baru yaitu:

\section{BiayaRupiah}

Daftar Ulang

SKS (per sks 65000) 20 sks

Rp 200.000

Operasional Pendidikan

Rp 1.300 .000

Dana Kemahasiswaan

Rp 1.960 .000

Koperasi Mahasiswa

Rp $\quad 15.000$

Paket Mahasiswa Baru

Rp $\quad 10.000$

Rp 500.000

Rp 3.985.000

\section{Sumbangan Gedung}

Grade A

Rp 6.000.000

Grade B

Rp 6.500.000

Grade C

Rp 7.000.000

Grade D

Rp 8.000.000

Rata-rata Sumbangan Gedung

Rp 6.875.000 
Berdasarkan biaya yang harus dikeluarkan mahasiswa, didapat rata-rata biaya semester awal: $\mathrm{Rp}$ 3.985.000 + Rp 6.875.000 = Rp 10.860.000. Biaya rata-rata semester awal ini dikurangkan dengan Dana kemahasiswaan, koperasi mahasiswa dan paket mahasiswa baru yang memang masing-masing telah dialokasikan menurut kebutuhannya. Jadi Rp 10.860.000 - Rp 525.000 = Rp 10.335.000. Berdasarkan data rata-rata dari bagian keuangan bahwa penggunaan dari rata-rata biaya yang harus dikeluarkan mahasiswa yang dipakai untuk operasional seperti gaji dosen dan karyawan, dan biaya lainnya mencapai $40 \%$. Sehingga manfaat bersih yang didapat dari setiap mahasiswa Rp 10.335.000 - Rp 4.134 .000 $=\mathrm{Rp} 6.201 .000$ dan mengalami kenaikan dengan asumsi 5\% per tahunnya agar harga kenaikan biaya kuliah selalu melihat kepada persaingan harga pendidikan sekolah tinggi swasta lainnya .

Tabel 9 dan Tabel 10 menjelaskan perkiraan pendapatan 5 tahun ke depan dari peningkatan jumlah mahasiswa baru.

Tabel 9. Perkiraan pendapatan dari peningkatan jumlah mahasiswa baru (tahun 1- tahun 3)

\begin{tabular}{|c|c|c|c|c|c|c|}
\hline $\begin{array}{c}\text { Program } \\
\text { Studi }\end{array}$ & \multicolumn{2}{|c|}{ Tahun ke-1 } & \multicolumn{2}{|c|}{ Tahun ke-2 } & \multicolumn{2}{|c|}{ Tahun ke-3 } \\
\hline Rata-rata & \multicolumn{2}{|c|}{2.067 .000} & \multicolumn{2}{|c|}{2.170 .350} & \multicolumn{2}{|c|}{2.278 .868} \\
\hline $\begin{array}{l}\text { biaya } \\
\text { smstr } 1\end{array}$ & $20 \%$ & $\mathrm{Rp}$ & $20 \%$ & $\mathrm{Rp}$ & $20 \%$ & $\mathrm{Rp}$ \\
\hline TI & 62 & 128.154 .000 & 74 & 328.074 .240 & 89 & 579.973 .742 \\
\hline SI & 59 & 121.953 .000 & 71 & 312.199 .680 & 85 & 551.910 .497 \\
\hline SK & 7 & 14.469 .000 & 8 & 37.040 .640 & 10 & 65.480 .906 \\
\hline $\mathrm{AK}$ & 16 & 33.072 .000 & 19 & 84.664 .320 & 23 & 149.670 .643 \\
\hline Total & 144 & 297.648 .000 & 173 & 761.978 .880 & 207 & 1.347 .035 .788 \\
\hline
\end{tabular}

Tabel 9. Perkiraan pendapatan dari peningkatan jumlah mahasiswa baru (tahun 4-tahun 5)

\begin{tabular}{lrrrr}
\hline \multicolumn{1}{c}{$\begin{array}{l}\text { Program } \\
\text { Studi }\end{array}$} & \multicolumn{2}{c}{ Tahun ke-4 } & \multicolumn{2}{c}{ Tahun ke-5 } \\
\hline $\begin{array}{l}\text { Rata-rata } \\
\text { biaya }\end{array}$ & $20 \%$ & 2.392 .811 & \multicolumn{2}{c}{2.512 .451} \\
smstr 1 & & & $20 \%$ & Rp \\
\hline TI & 107 & 814.067 .015 & 129 & 1.109 .024 .539 \\
SI & 102 & 774.676 .676 & 122 & 1.055 .362 .062 \\
SK & 12 & 91.910 .792 & 15 & 125.212 .448 \\
AK & 28 & 210.081 .810 & 33 & 286.199 .881 \\
\hline Total & 249 & 1.890 .736 .293 & 299 & 2.575 .798 .930 \\
\hline
\end{tabular}

Pada Tabel 9 dan Tabel 10, jumlah mahasiswa baru mengalami kenaikan $20 \%$ per program studinya pada tahun sesudah tahun ke-1 berdasarkan jumlah kenaikan jumlah mahasiswa baru 1 tahun sebelumnya. Nilai manfaat bersih per program studi yang didapat untuk tahun pertama hanya diambil dari jumlah biaya rata-rata semester 1 dikalikan dengan jumlah mahasiswa baru. Sedangkan nilai manfaat bersih mulai tahun ke-2 sampai tahun ke-5 dijumlahkan dengan jumlah rupiah yang didapat tahun sebelumnya dari mahasiswa yang mendaftar pada tahun sebelumnya dan biaya yang harus dikeluarkan untuk mengambil kuliah pada 2 semester berikutnya.

\section{PENINGKATAN PRODUKTIVITAS MANAJE- MEN TINGKAT ATAS}

Melalui data warehouse diharapkan akan membantu perguruan tinggi untuk meningkatkan produktivitas manajemen tingkat atas. Diharapkan dengan dibuatkannya sebuah aplikasi yang dapat diakses langsung oleh manajemen tingkat atas maka komposisi kerja manajemen tingkat atas dapat lebih efektif sehingga produktivitas kerja manajemen tingkat atas akan lebih meningkat. Agak sulit untuk mengukur prosentase kerja masing-masing jabatan dan berdasarkan hasil wawancara dengan pihak manajemen tingkat atas maka Tabel 11 dan Tabel 12 adalah tabel yang menggambarkan komposisi kerja manajemen tingkat atas saat ini yaitu dimana Dekan = $50 \%$, Ketua Program Studi $=60 \%$ dan Sekretaris Program Studi $=70 \%$.

Tabel 11. Produktivitas manajemen tingkat atas sebelum implementasi proyek data warehouse

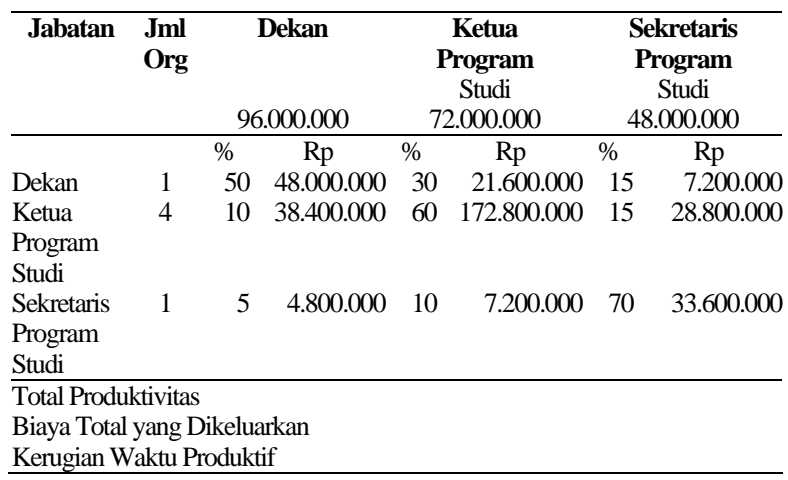

Tabel 12. Produktivitas manajemen tingkat atas sebelum implementasi proyek data warehouse (lanjutan)

\begin{tabular}{|c|c|c|c|c|}
\hline \multirow[t]{3}{*}{ Jabatan } & \multicolumn{2}{|c|}{ Non } & \multicolumn{2}{|c|}{ Total } \\
\hline & \multicolumn{2}{|c|}{0} & \multicolumn{2}{|c|}{216.000 .000} \\
\hline & $\%$ & $\mathrm{Rp}$ & $\%$ & $\mathrm{Rp}$ \\
\hline Dekan & 5 & 0 & 100 & 76.800 .000 \\
\hline Ketua & 15 & 0 & 100 & 240.000 \\
\hline $\begin{array}{l}\text { Program } \\
\text { Studi }\end{array}$ & & & & \\
\hline Sekretaris & 15 & 0 & 100 & 45.600 .000 \\
\hline Program & & & & \\
\hline Studi & & & & \\
\hline Total Prod & tivit & & & 362.400 .000 \\
\hline Biaya Tot & rang & luarkan & & 432.000 .000 \\
\hline Kerugian & ktu & ktif & & 69.600 .000 \\
\hline
\end{tabular}

Tabel 13 dan Tabel 14 adalah tabel yang mengkomposisikan peningkatan produktivitas kerja manajemen tingkat atas setelah pengimplementasian 
proyek data warehouse, dimana Dekan dari 50\% menjadi 65\%, Ketua Program Studi dari 60\% menjadi 75\% dan Sekretaris Program Studi dari 70\% menjadi 85\%. Peningkatan prosentase masing-masing jabatan tersebut didapat berdasarkan hasil wawancara dengan pihak manajemen tingkat atas, yang pada akhirnya diharapkan produktfitas manajemen tingkat atas dapat tercapai sesuai dengan penugasan jabatan manajemen tingkat atas tersebut masing-masing dan diharapkan keputusan-keputusan strategis yang akan ditentukan oleh manajemen tingkat atas ini lebih akurat dan terarah pada sasarannya.

Tabel 13. Produktivitas manajemen tingkat atas setelah implementasi proyek data warehouse

\begin{tabular}{|c|c|c|c|c|c|c|c|}
\hline \multirow[t]{2}{*}{ Jabatan } & \multirow[t]{2}{*}{$\begin{array}{l}\text { Jml } \\
\text { Org }\end{array}$} & \multicolumn{2}{|c|}{ Dekan } & \multicolumn{2}{|c|}{$\begin{array}{c}\text { Ketua } \\
\text { Program } \\
\text { Studi } \\
72.000 .000\end{array}$} & \multicolumn{2}{|c|}{$\begin{array}{c}\text { Sekretaris } \\
\text { Program } \\
\text { Studi } \\
48.000 .000\end{array}$} \\
\hline & & $\%$ & $\mathrm{Rp}$ & $\%$ & $\mathrm{Rp}$ & $\%$ & $\mathrm{Rp}$ \\
\hline Dekan & 1 & 65 & 62.400 .000 & 25 & 18.000 .000 & 10 & 4.800 .000 \\
\hline Ketua & 4 & 15 & 57.600 .000 & 75 & 216.000 .000 & 5 & 9.600 .000 \\
\hline $\begin{array}{l}\text { Program } \\
\text { Studi }\end{array}$ & & & & & & & \\
\hline $\begin{array}{l}\text { Sekretaris } \\
\text { Program } \\
\text { Studi }\end{array}$ & 1 & 2 & 1.920 .000 & 8 & 5.760 .000 & 85 & 40.800 .000 \\
\hline $\begin{array}{l}\text { Total Pro } \\
\text { Biaya To } \\
\text { Kerugian }\end{array}$ & yar & Dik & larkan & & & & \\
\hline
\end{tabular}

Tabel 14. Produktivitas manajemen tingkat atas setelah implementasi proyek data warehouse (lanjutan)

\begin{tabular}{|c|c|c|c|c|}
\hline \multirow[t]{3}{*}{ Jabatan } & \multicolumn{2}{|c|}{ Non } & \multicolumn{2}{|c|}{ Total } \\
\hline & \multicolumn{2}{|c|}{0} & \multicolumn{2}{|c|}{216.000 .000} \\
\hline & $\%$ & $\mathrm{Rp}$ & $\%$ & $\mathrm{Rp}$ \\
\hline Dekan & 0 & 0 & 100 & 85.200 .000 \\
\hline Ketua & 5 & 0 & 100 & 283.200.000 \\
\hline \multicolumn{5}{|l|}{ Program } \\
\hline \multicolumn{5}{|l|}{ Studi } \\
\hline Sekretaris & 5 & 0 & 100 & 48.480 .000 \\
\hline \multicolumn{5}{|l|}{ Program } \\
\hline \multicolumn{5}{|l|}{ Studi } \\
\hline \multicolumn{3}{|c|}{ Total Produktivitas } & & 416.880 .000 \\
\hline \multicolumn{3}{|c|}{ Biaya Total yang Dikeluarkan } & & 432.000 .000 \\
\hline \multicolumn{3}{|c|}{ Kerugian Waktu Produktif } & & 15.120 .000 \\
\hline
\end{tabular}

Dari hasil perbandingan kerugian waktu produktif sebelum dan sesudah implementasi maka didapat rekapitulasi efisiensi produktivitas kerja tahun pertama: Rp 69.600.000 - Rp 15.120.000 = Rp 54.480.000. Setiap tahun seterusnya lima tahun ke depan akan mengalami peningkatan 10\% dengan asumsi adanya kenaikan gaji 10\% per tahun, hal ini didasarkan pada asumsi inflasi rupiah dan penyesuaian Upah Minimum Regional (UMR) sebesar 10\% pertahun yang terlihat pada Tabel 15 .
Tabel 15. Rekapitulasi efisiensi produktivitas kerja

Tahun ke-1 Tahun ke-2 Tahun ke-3 Tahun ke-4 Tahun ke-5 \begin{tabular}{lllll}
54.480 .000 & 59.928 .000 & 65.920 .800 & 72.512 .880 & 79.764 .168 \\
\hline
\end{tabular}

\section{PERHITUNGAN SIMPLE ROI}

Perhitungan ROI ini digunakan untuk melihat apakah proyek data warehouse pada perguruan tinggi ini layak untuk diimplementasikan. Perhitungan untuk mendapatkan nilai arus kas bersih yaitu dengan menjumlah semua manfaat yang diperoleh dan dikurangkan dengan seluruh biaya. Nilai arus kas bersih ini yang dipakai untuk menghitung nilai prosentase ROI. Berikut ini penjelasan sesuai dengan perhitungan di atas yaitu:

Penerimaan Mahasiswa baru

20.619.593.679

Peningkatan produktivitas

manajemen tingkat atas

332.605 .848

Manfaat Ekonomi Bersih

20.952.199.527

Pengurangan Biaya Operasional

1.341.183.631

Pendapatan Sebelum Pajak

22.293.383.158

Biaya Berjalan

212.085 .850

Arus Kas Bersih

22.081.297.308

Pada akhirnya nilai prosentase ROI akan didapat dari Total arus kas bersih dibagi dengan 5 tahun dan dibagi lagi dengan nilai investasi bersih proyek yaitu: 22.081.297.308 / $5 / 238.700 .000=1850,13 \%$

Tabel 16 menjelaskan bagaimana lebih lanjut:

\section{Tabel 16. Perhitungan ROI}

\begin{tabular}{llr}
\hline a & Inventasi Proyek & 238.700 .000 \\
b & Arus Kas Tahunan : untuk periode 5 tahun & \multicolumn{1}{c}{ Total } \\
& & 20.952 .199 .527 \\
& Manfaat Ekonomi Bersih & 20.619 .593 .679 \\
& Penerimaan Mahasiswa baru & \\
Peningkatan produktivitas manajemen & 332.605 .848 \\
tingkat atas & 1.341 .183 .631 \\
Pengurangan Biaya Operasional & 22.293 .383 .158 \\
Pendapatan Sebelum Pajak & 212.085 .850 \\
Biaya Berjalan & 22.081 .297 .308 \\
Arus Kas Bersih & $1850.13 \%$ \\
\hline
\end{tabular}

Untuk penjelasan ROI yang menjelaskan secara detail selama 5 tahun dapat dilihat pada lampiran. Berdasarkan data ROI yang mencapai 1850,13 \% dan total arus kas bersih yang mencapai Rp 22.081.297.308 maka sudah dipastikan bahwa proyek data warehouse pada perguruan tinggi layak untuk diimplementasikan. 


\section{DAFTAR PUSTAKA}

1 Ponniah. P. 2001. Data warehousing fundamentals. John wiley\&Sons. Inc.

2 Gupta. V. R. 1997. An Introduction to Data Warehousing. Akses terakhir 9 Januari 2008 dari: www.system-services.com/DataWarehousing. asp.

3 McMeekin. A. 2000. Strategic IT Issues for Higher Education. Akses terakhir 20 Januari 2008 dari: www.its.monash.edu.au/aboutits/its-papers/ usvisit/

4 Anonymous. 1999. Minutes of the Decision Support/Data Warehouse Constituent Group EDUCAUSE '99. Long Beach (CA) Convention Center. Akses terakhir 10 Januari 2008 dari: www.educause.edu/elements/attachments/educau se/cg/ds_E99.pdf.

5 Ranti. B. 2005. Evaluasi Investasi Teknologi Informasi: Model dan Tipe Investasi. e-Indonesia. edisi 04. Agustus 2005.

6 Ranti. B. 2005. Evaluasi Investasi Teknologi Informasi: Tipe Manfaat. e-Indonesia. edisi 05. September 2005.
7 Heise. D. 2002. Data Warehousing in Higher Education. Akses terakhir 1 Februari 2008 dari: www.dheise.andrews.edu/dw/DWData.htm.

8 Strange. K. 1997. Can Data Mart Grows ?. CIO Magazine. July 1. 1997. Akses terakhir: 4 Februari 2008 dari : www.gartner.com.

9 Parker. M. M.. Benson. R. J. dan Trainor. H.E. 1988. Information economics- linking business performance to information technology. Prentice Hall. New Jersey.

10 Allan. R. G. 2000. Snowflakes and Grain: snowflaking to meet a Design Constraint. Journal of Data Warehousing. Vol 5. No.3 (summer 2000). Akses terakhir 18 Januari 2008 dari: www.gwu.edu/ aapp/sdm.

11 Allan. R. G. 2001. Data Models for a Registrar's Data Mart. Journal of Data Warehousing. Vol 6. No.3(summer 2001). Akses terakhir 18 Januari 2008 dari: www.gwu.edu/ aapp/sdm. 